\title{
LJUDSKE UNIVERZE IN JAVNA MREŽA USTANOV ZA IZOBRAŽEVANJE ODRASLIH
}

Strokovnjaki s področja izobraževanja in še kdo se bomo globoko strinjali s trditvijo, da je vitalnost naroda mogoče prepoznati tudi po njegovem znanju in splošni učljivosti. Novi izzivi ter prilagajanje socialnega, ekonomskega in kulturnega življenja postavljajo tudi izobraževalni sistem ter urejanje tega področja $v$ Sloveniji pred nova vprašanja. Nanja bomo morali odgovoriti, predvsem pa ukrepati dovolj naglo, da bomo zagotovili uspešno prilagajanje normativne in sistemske ureditve izobraževanja odraslih.

Vloga ljudskih univerz je na tem mestu gotovo še vedno nepogrešljiva, zgodovina delovanja in dejavnost pa segata $v$ čas pred skoraj sto leti. V takšni ali drugačni organizacijski obliki so ljudske univerze pomembno prispevale $k$ razvoju andragoške stroke in oblikovanju prakse izobraževanja odraslih.

Mogoče bo prispevek na prvi pogled nekoliko enostranski, pa vendar $v$ skladu s presojo uredništva tokrat za uvod predstavljamo delovanje mreže javnih organizacij na področju izobraževanja odraslih, pri čemer ne gre zanemariti vseh prizadevanj drugih organizacij, ki so nastajale kasneje in ki prav tako skrbijo za rast in razvoj področja.

\section{RAZVOJ LJUDSKIH UNIVERZ NA OBMOČJU SLOVENIJE}

Kratek pregled zgodovine razvoja javnih organizacij za izobraževanje odraslih kaže, da so $v$ mnogih evropskih državah ljudske univerze

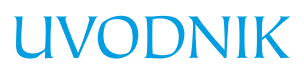

nastajale že od sredine 19. stoletja, v državah nekdanje Avstro-Ogrske pa ob koncu 19. stoletja, medtem ko se na območju Slovenije pojavijo na začetku 20 stoletja. V tistih časih so bile to edine ustanove, ki so izvajale različne oblike organiziranega učenja in izobraževanja odraslih.

Vzporedno z dejavnostjo v praksi se je na svoj način razvijala tudi teorija, kjer ni mogoče zaobiti pomembnega slovenskega pedagoga in filozofa (pripadnika kulturne pedagogike), ki je dobro razumel filozofijo vseživljenjskega učenja. Karla Ozvalda, dekana in profesorja Filozofske fakultete v Ljubljani, uvrščamo med pionirje teoretike vseživljenjskega učenja, saj v knjigi, ki jo je podnaslovil Kažipot za umevanje včlovečevanja, trdi, da je šolska izobrazba le priprava na poznejše izobraževanje v odrasli dobi. Kulturna pedagogika (p)ostaja aktualna tudi danes, saj tistim, ki jo berejo »v duhu in resnici, ne samo z očmi ali ustnicami«, pomeni nenehen izvir navdiha: bodisi za njihovo poklicno pedagoškoandragoško delo bodisi za lastno osebnostno rast. Kot redni profesor filozofske fakultete je Ozvald med drugim leta 1921 dal tudi pobudo za ustanovitev Akademskega socialno-pedagoškega krožka, katerega cilj je bila najširša razprava o aktualnih socialno-pedagoških vprašanjih. V sklopu tega krožka je bila ustanovljena tudi Delavska ljudska visoka šola, ki se je pozneje preimenovala v Ljudsko šolo. Tako akademski krožek kot ljudska šola sta pod Žgečevim vodstvom delovala pet let 
(Vidmar, 2000). Trideseta leta 20. stoletja so torej precej dobro izpostavila izobraževanje odraslih pri nas, tako v teoriji kot v praksi.

Rezultat razvoja delovanja in gibanja ljudskih univerz v bivši Jugoslaviji se je pokazal v pobudi Zveze sindikatov in Zveze Svobod, ko so delavske in ljudske univerze leta 1959 ustanovile krovno asociacijo, Zvezo delavskih in ljudskih univerz Slovenije (v nadaljevanju: Zveza), ki je ob nastanku združevala 78 članic v Sloveniji in je bila članica krovne zveze v bivši Jugoslaviji. Z gotovostjo lahko trdimo, da je Zveza v Sloveniji skupaj s svojimi članicami zaorala ledino na področju izobraževanja odraslih in andragogike pri nas. Njeno glavno poslanstvo je bilo zagotavljanje strokovne programske, organizacijske, andragoške, metodološke pomoči delavskim in ljudskim univerzam. V letih od 1960 do 1991 je bila edina krovna organizacija, ki je povezovala izvajalske organizacije na področju izobraževanja odraslih. Odigrala je izjemno pomembno vlogo pri razvoju andragogike, sistema izobraževanja odraslih in kakovosti na področju izobraževanja odraslih. Širša programska in vsebinska naravnanost Zveze je bila pravšnja podlaga za razmišljanja o potrebi po širši, neprofesionalni asociaciji, ki bi skrbela za splošni razvoj izobraževanja odraslih in andragogike. To je pripeljalo do pobude (ki je prišla iz Beograda; več o tem v: Jelenc: »Vloga in razvoj Andragoškega društva Slovenije«) za ustanovitev Andragoškega društva Slovenije leta 1968. V šestdesetih letih je bila prav Zveza največja krovna strokovna asociacija, ki je bila najintenzivneje povezana $z$ dejavnostjo izobraževanja odraslih in kjer se je najbolj porajalo in razvijalo andragoško znanje. Zveza delavskih in ljudskih univerz pa je ob ustanovitvi vključevala tudi nekatere druge organizacije, ki so izvajale programe za izobraževanje odraslih, na primer izobraževalne centre pri podjetjih in takratnih delovnih organizacijah. Zveza sicer ni nastala na podlagi zakonske obveznosti ali opredelitve, temveč je bila asociacija, ki se je odzvala takratnim družbenim in strokovnim potrebam. Vendar je zakon, ki je prvič bolj specifično in izrecno zakonsko opredelil delovanje Zveze (tedaj imenovane Zveza delavskih univerz), Zakon o delavskih univerzah, izobraževalnih centrih in drugih organizacijah, ki se poleg šol ukvarjajo z izobraževanjem odraslih (1971), opredelil organizacije javne mreže in njihovo organiziranost, kar je pomenilo tudi financiranje iz javnih sredstev.

V 90. letih 20. stoletja je tudi Zveza delavskih in ljudskih univerz Slovenije, tako kot nova država Slovenija, preživela obdobje tranzicije ter organizacijsko, finančno in programsko prestrukturiranje. Temu so pripomogle tudi velike sistemske, normativne in finančne spremembe na nacionalni ravni:

- pojav rastočega izobraževalnega trga na področju izobraževanja odraslih;

- proces privatizacije in pojav zasebnih izobraževalnih organizacij;

- priprava in sprejem nove sistemske zakonodaje in med drugim tudi zakona o izobraževanju odraslih;

- ustanovitev Andragoškega centra Slovenije kot osrednje razvojne in raziskovalne institucije na področju izobraževanja odraslih;

- sprememba sistema financiranja izobraževanja odraslih s prehodom na programsko-projektno financiranje ter kombinacijo financiranja prek javnih razpisov in financiranja infrastrukturnih dejavnosti.

Zveza delavskih in ljudskih univerz Slovenije se je preimenovala $v$ Zvezo ljudskih univerz Slovenije (ZLUS) in na novo opredelila svoje poslanstvo, razvojno strategijo, naloge in strateške cilje. Hkrati se je konec 90. let 20. stoletja z reorganizacijo delovanja Zveze članstvo drastično zmanjšalo (članice so le javne organizacije izobraževanja odraslih, ne več tudi zasebni ali izobraževalni centri pri podjetjih idr.), zmanjšalo se je tudi število profesionalno 
zaposlenih delavcev $v$ strokovni službi ZLUS, ki je prestala programsko in finančno reorganizacijo. ZLUS je v letih 2002 in 2004 na novo ustanovila svojo strokovno službo, članstvo in program dela $v$ obliki projektnih nalog ter ponovno pridobila in okrepila svoj položaj pomembnega strateškega in strokovnega partnerja državnim organom in strokovnim institucijam na nacionalni ravni. ${ }^{1}$

\section{JAVNA MREŽA IN IZVAJANJE JAVNIH PROGRAMOV}

Kratek pregled pomembnosti dela ljudskih univerz, predvsem z vidika izvajanja programov in organizacije različnih zvrsti in oblik izobraževanja odraslih ter zagotavljanja splošnih (javnih) programov v okviru javne mreže organizacij, kaže tudi na visoko stopnjo odgovornosti za so-oblikovanje politike izobraževanja in skrbi za izobraženost odraslih v obdobjih pred osamosvojitvijo Slovenije. To predstavlja raziskava, katere predmet raziskovanja so bile vsebine, programi in delo učiteljev ljudskih univerz v obdobju po drugi svetovni vojni in pred osamosvojitvijo Slovenije - Ljudske in delavske univerze v obdobju od 1945 do 1990. ${ }^{2}$ Raziskava podrobneje prikazuje pomen in vpliv delavskih ter ljudskih univerz ${ }^{3}$ na prebivalce v Sloveniji. V času ljudskih univerz kot amaterskih združenj (v 50. letih) je udeležba na področju splošnega izobraževanja skoraj nenehno naraščala, in to vse do študijskega leta 1961/1962, ko se je število udeležencev od leta 1956 povečalo skoraj za trikrat. V tem obdobju, v letih od 1947 do 1991, naj navedem le kot zanimivost, je bilo $v$ vse organizirane izobraževalne oblike (tako krajše kot daljše, npr. predavanja, seminarji in šole za odrasle) vključenih kar 12,767.963 udeležencev. Podatek ni najbolj aktualen in ne omogoča večjih posploševanj, vseeno pa kaže, da so imele ljudske in delavske univerze nezanemarljiv vpliv na zelo veliko ljudi v obravnavanem obdobju (Mohorčič - Špolar, Emeršič, 1999).
$V$ skladu z novo vlogo ljudskih oziroma delavskih univerz $v$ začetku 60. let pa je začela strmo padati tudi udeležba na področju splošnega izobraževanja. Podatki kažejo, da so v tem obdobju delavske in ljudske univerze usmerile vse svoje sile v pripravo in organizacijo drugih vrst izobraževanja - predvsem na področju družbeno-politične vzgoje, kasneje pa še $v$ organizacijo predavanj iz obrambne vzgoje, ki jo je pogojevala takratna politika. Splošno izobraževanje je bilo tako prepuščeno trgu. Udeleženci izobraževanja odraslih so, razen pri določenih izjemah, $v$ celoti plačali stroške izobraževanja (brezplačnih je bilo le nekaj vsebin, npr. predavanja iz ciklusa šole za starše). Udeležba v teh izobraževanjih je bila tako prostovoljna, samo interes posameznikov zanj pa je bil pogosto premalo, zato se je $v$ študijskem letu 1980/1981 v splošno izobraževanje vključilo le 241 udeležencev.

Podatki iste raziskave kažejo, da je do leta 1958, ko so bile ljudske univerze organizirane kot amaterska društva, delež udeležbe odraslih v izobraževanju nihal med 5 in 18 odstotki celotne odrasle populacije. $Z$ njihovo profesionalizacijo in preobrazbo $v$ organizacije $z a$ izobraževanje odraslih se je skokovito povečala tudi udeležba, saj se je delež vključenih $v$ izobraževanje $v$ študijskem letu 1959/1960 povzpel na 31 odstotkov.

Kasnejše vmesne padce vključenosti odraslih lahko najpogosteje povezujemo s splošnimi družbeno-političnimi razmerami, ki so spodbujale ali pa zavirale razvoj izobraževanja odraslih. To se kaže predvsem v tem, da v posameznih obdobjih zasledimo večjo podporo države, predvsem splošnemu izobraževanju, pa tudi poklicnemu in drugim oblikam učenja, v drugih obdobjih pa država bodisi kaže naklonjenost samo izobraževanju, ki vzdržuje obstoječo družbeno-politično naravnanost, ali pa sploh ne podpira niti izvajanja programov, kaj šele razvoja izobraževanja odraslih. 
Tako je na primer konec 60. let na delovanje delavskih univerz močno vplivala liberalizacija družbe, ki se je odrazila predvsem v bolj tržno usmerjeni programski zasnovi in razmeroma manjšemu političnemu vmešavanju države, kar je povzročilo najbolj izrazit upad tistega izobraževanja, ki je bilo tudi državno najbolj podprto. Konec 60. let pa so se začeli stopnjevati politični pritiski na zasnovo in delovanje delavskih univerz, ki so kulminirali v začetku študijskega leta 1970/1971, ko se je delež udeležencev povzpel v celotnem obravnavanem obdobju najvišje, do 35-odstotne udeležbe odraslih v izobraževanju.

Eden bolj dramatičnih podatkov je s konca 80. let, ko je delež udeležencev v izobraževanju odraslih padel na raven iz leta 1950 oziroma na pet odstotkov (celotne populacije), kar bi lahko razložili s skoraj popolnim umikom države in prepuščanjem izobraževanja odraslih tržnim zakonitostim oziroma interesom in finančnim zmožnostim samih udeležencev. To tezo potrjujejo tudi podatki, predstavljeni ob Dnevu ljudskih univerz, ${ }^{4}$ ki kažejo, da si je takrat približno 70 odstotkov udeležencev $v$ programih izobraževanja na ljudskih in delavskih univerzah plačevalo stroške izobraževanja. Upad splošnega izobraževanja je komentiral v tistem času tudi Ivo Tavčar, ${ }^{5}$ ki je konec 70 . let opazil, da so tako politične organizacije kot kulturne ustanove popolnoma nezainteresirane za kulturno oziroma splošno izobraževanje.

Iz raziskave z naslovom Odrasli prebivalci Slovenije v izobraževanju 6 lahko za leto 1987 primerjamo empirično dobljene podatke o udeležbi s statističnimi podatki takratnega Zavoda za statistiko. Zaradi različnih metodologij pri zbiranju podatkov in zaradi težav pri razmejitvi med udeležbo in vključitvami je razumljivo, da se deleži razlikujejo, vendar pa so tovrstne primerjave zanimive zato, ker se z njimi lahko, vsaj okvirno, bolj približamo dejanskemu stanju. V omenjeni raziskavi lahko za delavske univerze razberemo, da so se njihovih izobraževalnih programov udeležili trije odstotki odraslih, medtem ko lahko iz dosegljivih statističnih podatkov razberemo, da je bilo v letu $1987 v$ delavske univerze vključenih osem odstotkov celotne populacije. Omenjena raziskava je zanimiva tudi zato, ker navaja, da je udeležba $v$ delavskih univerzah tvorila kar četrtino vseh udeležb v izobraževanju odraslih v primerjavi s preostalimi izobraževalnimi organizacijami oziroma da so delavske univerze imele njihov največji delež.

$V$ tem kratkem pregledu vključenosti odraslih $v$ splošno izobraževanje in drugo izobraževanje $v$ preteklosti ter nihanja vključenosti v splošno izobraževanje in kazalcev podpore države splošnemu izobraževanju odraslih vidimo odsev različnih struj $v$ takratni družbi in politiki, kar se odraža tudi v tem, kako in koliko je bilo to področje podprto z javnimi finančnimi sredstvi.

Danes dosegljivi podatki v okviru analize ReNPIO, kjer Slovenija sledi lizbonski strategiji in ciljem, s katerimi je usklajen tudi nacionalni program izobraževanja odraslih, kažejo, da je 15 odstotkov odraslih (med 15. in 64. letom) vključenih $v$ vseživljenjsko učenje in izobraževanje. Po prioritetnih področjih iz omenjene resolucije je prvo med njimi tudi splošno izobraževanje, med operativnimi cilji pa je povečanje stopnje vključenosti v splošno izobraževanje (to ne vključuje izobraževanja za trg dela in izboljšanje izobrazbe), ki jo bomo Slovenci po sedanjih projekcijah v letih od 2003 do 2010 zvišali s 3,5 odstotka na 6 odstotkov in celo presegli.

Podatki v šolskih letih od 2001 do 2006 kažejo, da je v izobraževanje vključenih povprečno 22 odstotkov prebivalcev $v$ starosti od 15 do 64 let, vendar je med njimi več kot 80 odstotkov udeležencev obiskovalo programe za potrebe poklicnega dela. Razveseljivo je, da je delež 
udeležencev, ki jih zanimajo programi za splošne potrebe in prosti čas, ki je v šolskem letu 2004/2005 dosegal le 11 odstotkov, v šolskem letu 2005/2006 spet narasel na 16 odstotkov. ${ }^{7}$ Zgornje podatke lahko primerjamo z nekaterimi iz preteklosti. Na prvi pogled je primerjavo mogoče označiti kot grobo špekulacijo, pa vendar če pozorno pogledamo nekatere odstotke, lahko sklepamo, da so se odrasli v nekaterih obdobjih celo bolj intenzivno učili in izobraževali, kot se danes, in vse to na račun javnih sredstev.

Programi ljudskih univerz in javna služba na področju izobraževanja odraslih so pomembna sestavina celotnega sistema izobraževanja $v$ Sloveniji in $v$ potrebnih segmentih zagotavljajo tudi izvajanje programov ter dejavnosti, ki so v javnem interesu.

Vokvir prioritetnih področij ReNPIO in uspešnega zagotavljanja vseživljenjskega učenja ter uresničevanja Strategije vseživljenjskega učenja ${ }^{8}$ sodijo tudi programi splošnega izobraževanja, ki jih izvajajo ljudske univerze.

Pri tem je pomembno opredeliti in pojasniti, kaj pomeni javni interes: »Javni interes je tisti, ki lahko v nekaterih primerih zahteva varovanje pravic diskriminiranih skupin prebivalstva prek javnih služb... Popolnoma enake razmere se seveda pojavijo, kadar domače podjetje grozi z monopolizacijo trga. Vse države se tega branijo z regulativo o varstvu konkurence. Javni interes torej tukaj nastopa $v$ funkciji uresničevanja vrhovnega nacionalnega ekonomskega interesa " (Jože P. Damijan, 2002). ${ }^{9}$ Definicijo javne službe pa bi lahko strnili takole: »Javna služba na področju izobraževanja odraslih je javni interes in naročilo $v$ obliki programov ter dejavnosti, opredeljenih z zakonom oziroma z odlokom občine ali mesta, katerih trajno in nemoteno opravljanje zagotavlja v javnem interesu država, občina ali mesto ${ }^{10}{ }^{10}$ kar je opredeljeno v obstoječi zakonodaji: Zakonu o zavodih (Ur. l. RS, št. 12/91,
17/91, 55/92, 66/93, 8/96, 36/2000)-22. člen; Zakonu o organizaciji in financiranju vzgoje in izobraževanja (Ur. l. RS št. 98/2005) (velja od 14. marca 1996) - 10., 28. člen; Zakonu o izobraževanju odraslih Ur.l. RS št. 12/96, 86/2004 in 69/2006) - 22., 23., 24., 25. in 26. člen.

$Z$ uvedbo novih načinov financiranja, predvsem s sredstvi Evropskega socialnega sklada, se je Sloveniji omajala shema razmeroma stabilnega financiranja razvoja in izvajanja javnih programov ter javne službe. Hkrati pa bi predlagana podrobnejša analiza stanja rezultatov na področju izvajanja javne službe na področju izobraževanja odraslih in preučitev razvojnih prioritet na področju javne službe izobraževanja odraslih v naslednji razvojni perspektivi 2007-2013 (pa tudi uvedba nekaterih ukrepov za ohranitev in izboljšanje javne službe izobraževanja odraslih v novi finančni perspektivi) lahko vnesli več stabilnosti $v z a$ gotavljanje delovanja javne službe in vzdrževanje javne mreže ustanov, ki v razmeroma veliki meri skrbijo za izvajanje splošnih programov za izobraževanje odraslih $v$ skladu $z$ uresničevanjem koncepta vseživljenjskega učenja. Tako so na primer ljudske univerze tiste, ki edine izvajajo osnovno šolo za odrasle, prav tako Program svetovalnih središč, pri ljudskih univerzah deluje 68,8 odstotka središč za samostojno učenje, 20 odstotkov dejavnosti Borze znanja, 16 odstotkov študijskih krožkov in 29 odstotkov programov za znižanje izobrazbenega primanjkljaja. Iz projektnega financiranja iz javnih sredstev se je na ljudskih univerzah izvajalo 62 odstotkov računalniškega opismenjevanja, 54 odstotkov projekta POKI (Ponudimo odraslim kakovostno izobraževanje) in 42 odstotkov dejavnosti svetovalcev za kakovost. ${ }^{11}$

Iz podatkov v prejšnjem odstavku o črpanju javnih sredstev prek javnih razpisov, ki jih izvaja ministrstvo za šolstvo in šport za področje 
izobraževanja odraslih, je razvidno, da ljudske univerze izvedejo 61,8 odstotka programskega dela teh sredstev (Sotošek, 2006).

$V$ zadnjih dveh letih se je dobesedno porušila shema financiranja javne mreže, kar je omajalo razmeroma stabilen status javnih organizacij za izobraževanje odraslih - ljudskih univerz $v$ Sloveniji, saj so kot prejemnice sredstev Evropskega socialnega sklada za izpeljavo projektov in programov iz tega naslova zašle $v$ hude finančne težave.

Te razmere so resno ogrozile obstoj mreže javnih organizacij, s tem pa tudi izvajanje javne službe $z$ dolgoletno tradicijo.

$V$ naslednji finančni perspektivi so ljudske univerze poleg osnovne šole in prej navedenih programov ter dejavnosti tudi stoodstotne nosilke nadaljnjega razvoja 14 tako imenovanih centrov vseživljenjskega učenja, ki združujejo lokalna in regionalna partnerstva s področja vseživljenjskega učenja $v$ skupni vrednosti 12,503.163 evrov. Podatek kaže na obsežnost projektov in nedosledno financiranje $v$ podob- nih okoliščinah, ki smo jim bili nekoč že priče, lahko povzroči zlom javne mreže organizacij. Tako stanje bi lahko resno ogrozilo zagotavljanje splošnega izobraževanja odraslih in nujnega vzdrževanja razvoja, izobraževanja kadrov in mreže javnih organizacij v Sloveniji, kot se je to zgodilo konec 60. let.

Naj končam z mislijo, da je kljub uresničevanju velikih ciljev slovenska zakonodaja, $k i$ ureja izobraževanje odraslih, milo rečeno, zastarela. Sistemu izobraževanja se pozna arhaičen pristop bolj kot kateremu koli drugemu resorju $v$ državi, birokratskim strukturam pa slaba prilagodljivost novim načinom ravnanja z javnimi sredstvi. Le želimo si lahko, da bomo v čim krajšem času prerasli strah pred spremembami in se čim prej sistematično ter strokovno lotili spreminjanja in prilagajanja normativnih in zakonodajnih vprašanj. Le tako bomo lahko zagotovili ustrezne pogoje za izobraževanje odraslih $v$ celoti in iz javnih sredstev poskrbeli za tista prioritetna področja, ki smo jih opredelili v pomembnih državnih dokumentih, ki so usklajeni z evropskimi usmeritvami in cilji.

Ema Perme

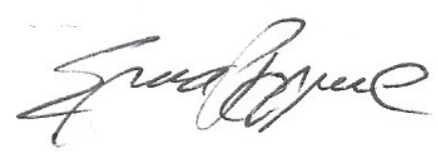

